\title{
Caracterization and Compressive Strength of Biocomposite Hydroxyapatite-Borosilicate with Hight Temperature Sintering
}

\author{
Burmawi $^{1,2}$,Novesar Jamarun ${ }^{2 *}$, Syukri Arief ${ }^{2}$, Gunawarman $^{3}$ \\ ${ }^{1,2}$ Department of Mechanical Engineering, Bung Hatta University, Padang Indonesia \\ ${ }^{2}$ Department of Chemistry, Andalas University, Padang Indonesia \\ ${ }^{3}$ Department of Mechanical Engineering, Andalas University Padang Indonesia
}

\begin{abstract}
The use of Hydroxyapatite as bone graft material continues to increase. To utilize hydroxyapatite, it is often formed into biocomposite. The formation of hydroxyapatite biocomposite intended to address the fragile hydroxyapatite weaknesses. The added element in the formation of this biocomposite is borosilicate. Mixing of this material is arranged with certain composition using ball miling. To form a test specimen, it was printed with compacting force of $5 \mathrm{KN}, 15 \mathrm{KN}$ and $25 \mathrm{KN}$. Test results Compressive Strength.and XRD showed that addition of borosilicate did not change the compound that is hydroxyapatite, but the intensity of hydroxyapatite tends to decrease with addition of borosilicate amount, this is corroborated by FTIR testing. For visible compressive strength, the maximum value occurs at 75: 25 compositions, ie $45 \mathrm{MPa}, 42.9 \mathrm{MPa}$ and $52.3 \mathrm{MPa}$. This suggests that the addition of borosilicate in biocomposite formation does not alter hydroxyapatite compound and can generally increase the compressive strength and modulus of elasticity to $25 \% \mathrm{wt} \%$ borosilicate addition.
\end{abstract}

\section{Introduction}

Hydroxyapatite is a chemical compound $\mathrm{Ca}_{10}(\mathrm{PO})_{6}(\mathrm{OH})_{2}$ or HAp. It is an attractive and potential material used to repair bone, bone filler and biocomposite as well as for engineering scaffolds [1]. Hydroxyapatite can be obtained by various methods, including: precipitation, sol-gel, hydrothermal and mechanical [2]. Hidroksiapatit of bovine bone has advantages, among others, because it has physical and chemical properties that almost similar to human bones. Hydroxyapatite is also osteoconductivity, biodegradable and non-toxic.

Powder of bovine bone hydroxyapatite still has fragile mechanical properties. Therefore, to improve the mechanical properties, need to be formed into biocomposite material. Biocomposite is combination of two or more ingredients, each having a function as filler and as matrix. In this case hydroxyapatite as filler and borosilicate as a matrix. Silica can substitute phosphate compound in HAp, considering the average length of the bond between $\mathrm{Si}-\mathrm{O}$ and $\mathrm{P}-\mathrm{O}$ are $1.62 \AA$ and $1.51 \AA$. Therefore, this substitution is likely to occur in PO4 3 with SiO44- [3]. The addition of borax material generates better inhibition of cell

\footnotetext{
* Corresponding author: novesar62@yahoo.com
} 
development in static conditions, making it excellent for bone growth [4. 5]. Sintering at a temperature of $1000^{\circ} \mathrm{C}$ to $1100^{\circ} \mathrm{C}$, forming a superplastic material. This happens because in sintering process there is an increase in granular density, but the strain will decrease [6].

In previous study [7], production of borosilicate-hydroxyapatite biocomposite with mold pressure of $70 \mathrm{~kg} / \mathrm{cm}^{2}$, borosilicate composition of 5,10 and $15 \mathrm{wt} \%$ and sintering temperature of $1000{ }^{\circ} \mathrm{C}$ also, providing maximum compressive strength of $3.48 \mathrm{MPa}$. In this study, the formation of the borosilicate-hydroxyapatite biocomposite besides analyzing the characteristics occurring by the addition of borosilicate compositions and compaction forces of $5 \mathrm{KN}, 15 \mathrm{KN}$ and $25 \mathrm{KN}$, it is also analyzed mechanical properties biocomposite material.

\section{Material and Methods}

This study was started from mixing of bovine hydroxyapatite material with silica material and borax acid with hydroxyapatite composition of 70, 75, 80, 85 and 90\% remaining weight is added with silica and borax acid. The mixing process is using ball miling with $200 \mathrm{rpm}$ rotation speed, $10 \mathrm{~mm}$ diameter ball as much as 25 pieces and performed for 60 minutes. To form a specimen, printing is conducted with compression force of $5 \mathrm{KN}, 15$ $\mathrm{KN}$ and $25 \mathrm{KN}$ and holding time of 10 minutes with a size of $10 \mathrm{~mm}$ and a height of $10 \mathrm{~mm}$. The sintering process is carried out at temperature of $1000^{\circ} \mathrm{C}$ for 3 hours. To check biocomposite characteristic, XRD test was performed using X-Ray Diffraction (XRD) with XRD XPERT Powder PW 30/40 and Fourier Transform Infra Red (FTIR) using FTIR Spectrometer Frontier with Perkin Elmer brand. The mechanical property test is a compressive strength test. Test of compressive strength is performed using universal press test machine with standart ASTM D3410.

\section{Results and discussion}

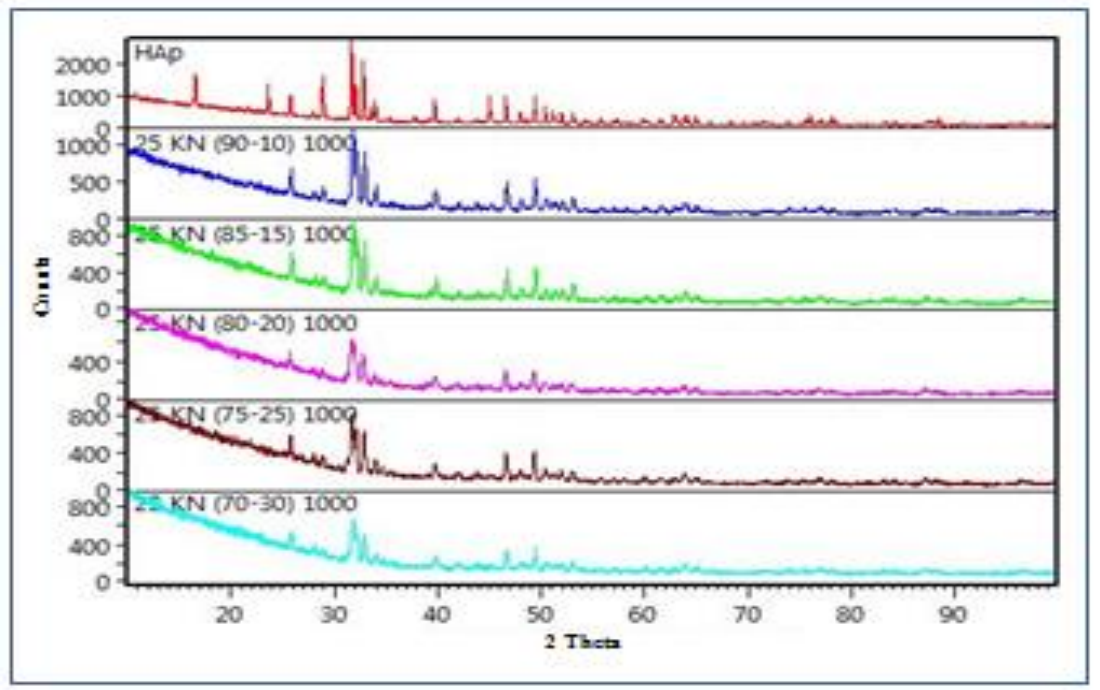

Fig 1. XRD test results with a variety of Borosilicate compositions

$\mathrm{XRD}$ testing is conducted to determine the compounds formed on the specimen. In Figure 1, it is seen that in pure HAp material, there is still PO4 NH4 pollutant. After adding borosilicate material with composition ranging from $10 \%$ and sintering treatment at a temperature of $1000^{\circ} \mathrm{C}$, it is seen that the pollutant on hydroxyapatite begin to disappear, and after 
examination with JCPDS, it turns out the compound formed in biocomposite Hydroxyapatite-Borosilicate is in the form of hydroxyapatite compound as well. This is seen at diffraction angle of $2 \theta$, it is not very different ie ranging from $31.7^{\circ}, 32.2^{\circ}$ and $32.9^{\circ}$ [8]. Similarly, other diffraction peaks formed the same chemistry of hydroxyapatite and this is an easy substitution of $\mathrm{SiO} 2$ in hydroxyapatite structure. The XRD profile was compared to bovine hydroxyapatite with HAp-Borosilicate biocomposite, and according to JCPDS 9-432, it showed similar hydroxyapatite [9]. However from this test, the more borosilicate, the less the intensity of hydroxyapatite compounds. This is affected by borosilicate intensity in bovine hydroxyapatite.

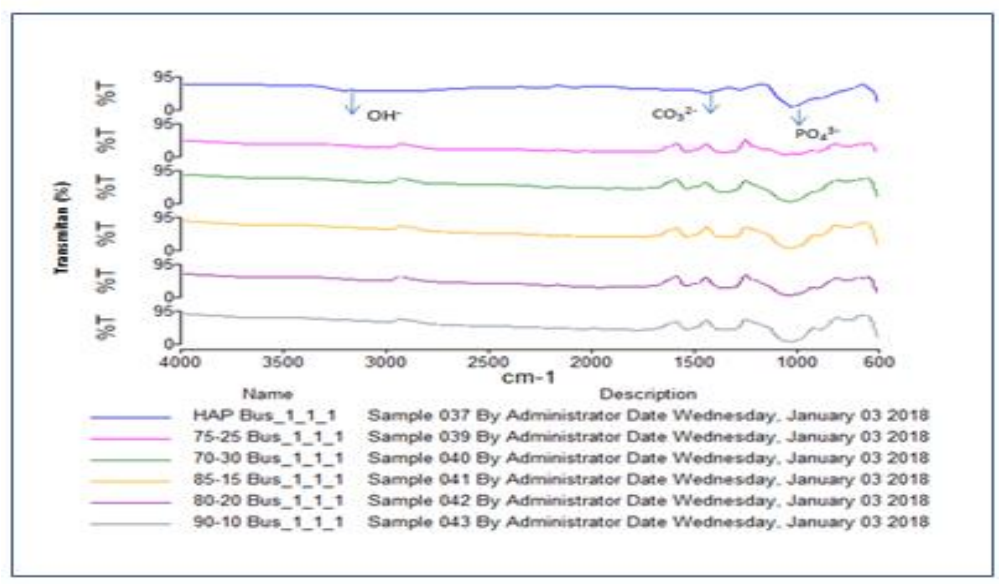

Fig. 2. FTIR test results with a variety of borosilicate compositions

The FTIR test is useful to know the functional group of compounds present in biocomposite of HAp-borosilicate. From infrared spectrum of hydroxyapatite, we saw functional groups of $\mathrm{CaO}, \mathrm{PO}_{4}$ and $\mathrm{OH}^{-}$. The wavelength formed gives information that the functional group of $\mathrm{PO}_{4}$ is formed at wavelength of $1015 \mathrm{~cm}-1,1061 \mathrm{~cm}-1,1026 \mathrm{~cm}-1$ and $1030 \mathrm{~cm}-1$. The $\mathrm{OH}^{-}$functional group is seen in almost all compositions at the wavelengths of $2214 \mathrm{~cm}-1,2026 \mathrm{~cm}-1$, and $2987 \mathrm{~cm}-1$. Wavelengths of $1267 \mathrm{~cm}-1,1264 \mathrm{~cm}-1$ and 1262 cm-1 prove that $\mathrm{SiO}_{2}$ is present in this biocomposite material [10]. Meanwhile, the wavelength of $1528 \mathrm{~cm}-1$ is formed. This indicates that a $\mathrm{CO}_{3}$-functional group [11] is formed as the effect of borosilicate addition on the formation of borosilicate hydroxyapatitebiocomposite

Compressive strength is used to determine the ability of biocomposite materials in accepting vertical loading to cross-section of the object. This is related to material application on human bone graft. [12] We have conducted a study on hydroxyapatite-PCL with addition of $10 \% \mathrm{~W} / \mathrm{v} \mathrm{PCl}$, giving compressive strength yield of $4.20 \pm 0.05 \mathrm{MPa}$ and elasticity modulus of $6.10 \pm 0.03 \mathrm{MPa}$. In addition, [13], adding silica to tricalcium phosphate provides compressive strength value of about $2 \mathrm{MPa}$.

In the study [14], PMMA-cement provides high compressive strength above $100 \mathrm{MPa}$, but its press elasticity modulus is quite low at around $2.5 \mathrm{Gpa}$. This means the material is quite brittle. Likewise, in the study [15], HA / PSSM composites with PSSM compositions of 5, 10 and $15 \%$, had tensile strength value of $16.20 \pm 1.73 \mathrm{MPa}$ to $23.96 \pm 2.56 \mathrm{MPa}$ and modulus of elasticity of 626.96 to $1026 \mathrm{MPa}$. When compared with the results of this study, it is noticed that a given mold compaction force varying $5 \mathrm{KN}, 15 \mathrm{KN}$ and $25 \mathrm{KN}$ gives promising results. The graph show the borosilicate composition given to hydroxyapatite has a significant effect on the compressive strength of biocomposite, in which the borosilicate functioned as a matrix with hydroxyapatite filler. Figures 3, 4 and 5 show that generally the 
more borosilicate composition, the higher compressive strength of the material. At a pressurized force of $5 \mathrm{KN}$, the maximum compressive strength of HAp-borosilicate biocomposite material is $45 \mathrm{MPa}$ at 75:25 compositions. The compacting force of $15 \mathrm{KN}$ gives maximum compressive strength of $42.9 \mathrm{MPa}$ also in the 75: 25 compositions. The compacting force of $25 \mathrm{KN}$ gives maximum compressive strength of $52.3 \mathrm{MPa}$ in 75:25 compositions

In this research, the result of this compressive strength of biocomposite is higher than PCL-hydroxyapatite composite, hydroxyapatite-PSSM as well as from Composite Tricalcium phosphate-silica but lower than Hydroxyapatite-PMMA biocomposite. It means that the material is more resilient than hydroxyapatite-PMMA. And when compared to previous studies [7], with the same material but different processes, the results obtained in this study are much higher. This can be seen from the compressive strength value obtained by $3.48 \mathrm{MPa}$ versus $32 \mathrm{MPa}$. According to the results of others' research [16] for cortical bone application with compressive strength of $30-160 \mathrm{MPa}$, it turns out that the compressive strength produced has met the range listed in the table and can be used.

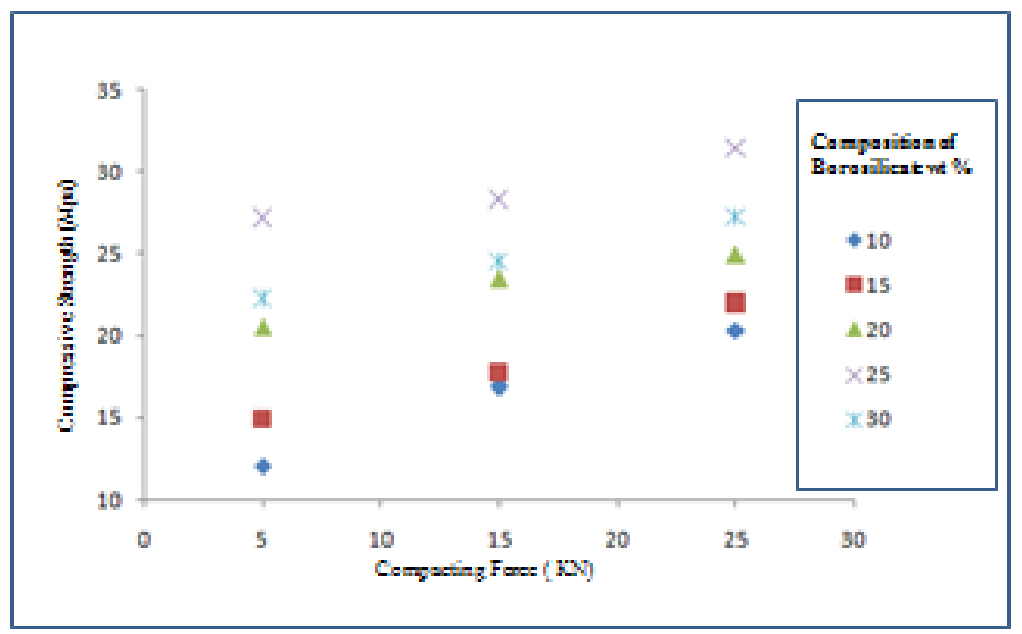

Fig. 3. HAp-Borosilicate biocomposite Compressive Strength with Compacting force of $5 \mathrm{KN}, 15 \mathrm{KN}$ and $25 \mathrm{KN}$

\section{Conclusion}

1. Addition of borosilicate to the formation of biocompositeHAp-borosilicate generally does not change the chemical formula of hydroxyapatite.

2. Maximum compressive strength is obtained in Borosilicate composition of $25 \mathrm{wt} \%$ for compacting force styles of $5 \mathrm{KN}, 15 \mathrm{KN}$ and $25 \mathrm{KN}$ at sintering temperature of $1000^{\circ} \mathrm{C}$ with values of $32 \mathrm{MPa}$.

Thanks to the Ministry of Research and Technology - Higher Education, Republic of Indonesia, which has helped finance this research

\section{References}

1. P. Ducheyne. S. Radin, L King. Journal Dissolution,J.Biomed.Mater.27,25- 34(1993) 
2. N. Jamarun, Z.Azharman, S.Arief, T.P.Sari, A.Asril, S.Elfina, Rasayan Journal Chemical, $8,1,133-137(2015)$

3. A. El Yacoubi. A. Massit, M.Fathi, B.Chafik, El Idris , K. Yamni, IOSRJAC, 7, 11,2429 (2014)

4. R.F. Brown. R.F, M.N.Rahman, Agatha B, Dwilewicz, W. Huang, Wiley Periodical, Inc. (2008)

5. K. Itatani. K. Tsuchiya, Y. Sakka, Davies. I.J, S. Koda, 31. 2641-2648 (2011).

6. S. Ramesh., K.L.Aw, R.Tolouei, M.Amiriyan, C.Y.Tan, M.Hamdi, J.Purbolaksono, M.A.Hasan, W.D.Teng, Ceramic International, 39, 111-119 (2013)

7. Burmawi, N. Jamarun, S.Arief and Gunawarman, Oriental Journal Of Chemistry, 33, 2, 920-924 (2017)

8. S. Amjuvan. S, H. Aspersa, Bull Material Science, 35, 6, 1031-1038 (2012)

9. E. Kusrini, A..R, Pudjiastuti, S. Astutiningsih and S. Harjanto, ICBEE'2012 (2012).

10. N.Fariba., M.A.S. Sadjadi, S.J.Fateami, M.K.Mobarakeh and R.M.Afshar, 32 3, 16391647(2016).

11. A.Khelendra, G Singh, D. Puri, S. Prakash, biomedical Application, 10, 727-734(2011)

12. K.J.U.Sharon and Nazmin S, Contact angle, ARPN, 11, 13686-13691, (2016.)

13. Lereley. M.A, R.G. Corrodeguos, L Alberto dos Santos, Material Research, 14, 475-482 (2011).

14. K.Serbetqi., F.Korkusuz, N.Hasirci, Turk J Med Sci, 30, 543-549 (2000).

15. Weng Hong Tham, M.U. Wahit, M.R.A. Kadir and T.W. Wong, , SJST, ,35, 1, 57-61. (2013). 